\title{
Free-Riders in the Nonprofit Industrial Complex: The Problem of Flexitarianism
}

\author{
Corey Lee Wrenn \\ Department of Political Science \& Sociology, Monmouth University, West \\ Long Branch, NJ \\ corey.wrenn@gmail.com
}

\begin{abstract}
Social movements have traditionally viewed free-riders as a problem for effective mobilization, but under the influence of the nonprofit industrial complex, it is possible that movements actively facilitate their presence. Free-riders become an economic resource to professionalized movements seeking to increase wealth and visibility in the crowded social movement space by discouraging meaningful attitude or behavior change from their audiences and concentrating power among movement elites. Actively cultivated free-riding is exemplified by the professionalized Nonhuman Animal rights movement which promotes flexitarianism over ethical veganism despite its goal of nonhuman liberation. Major social-psychological theories of persuasion in addition to 44 studies on vegan and vegetarian motivation are examined to illustrate how free-rider flexitarianism is at odds with stated goals, thereby suggesting an alternative utility in flexitarianism as a means of facilitating a disengaged public.
\end{abstract}

\section{Keywords}

animal rights - flexitarianism - free-rider problem - nonprofit-industrial complex veganism

\section{Introduction}

Motivating participation is a top priority for social movements. The presence of a large collective can help normalize activism as desirable, encouraging additional participation and lending credibility to movement goals. However, 
this vital participation is easily discouraged if bystanders rationalize that the movement can handle a social problem without additional assistance. Known as the free-rider problem, this conundrum would become central to social movement thought as theories of rationalization were applied to movement mechanisms in the mid-2oth century (Olson, 1968). When activism is perceived as especially costly, individuals may be compelled to leave the burden to others. Consequently, if few are willing to participate, the costs (time, risk, and resources) for those who are willing become significantly greater. Because many hands make light work, movements that enjoy greater participation could be better positioned for goal attainment. ${ }^{1}$ Free-riders can complicate this process considerably. With fewer participants, a movement may be less able to mobilize resources, leading to a weakened ability to negotiate social change.

This article suggests an alternative complication. It could be that freeriders hinder social movement success by diluting a social movement's carefully crafted identity ("this is who we are;" "this is what we do") as well as its proscription for change ("this is what we want") by identifying with a movement without contributing to it ("this is who I am" without "this is what I do"). Identity is a powerful means of mobilization and membership preservation (Armstrong, 2002; Hunt \& Benford, 2004; Meyer, Whittier, \& Robnett, 2002). It fosters a sense of belonging, and, as such, it is considered an important counterbalance to the many disincentives to participation. Free-riding has the potential to undermine this important movement resource.

It would be incorrect to suggest that free-riding is an uncontrollable nuisance. Instead, levels of free-riding are a response to movement behaviors as much as they are to personal character. In a case study of the American Nonhuman Animal ${ }^{2}$ rights movement, this article considers that the mobilization problems commonly attributed to free-riders may actually derive from structural conditions and social movement decision-making that erode motivational identity. In Western countries, social movements have been bound by the nonprofit industrial complex, a symbiotic system with the state that assures nonprofit growth and deradicalization (Rodríguez, 2007). Friedman and McAdam (1992) observe that nonprofitization threatens the potency of collective identity by forcing organizations into competition with one another. They also emphasize that identity, once created, is difficult to control, and freeriding becomes rampant without a cooperative movement space. In such a system, the presence of many free-riders may promote the concentration of

1 Research conducted since Olson's work on group size and the propensity for collective action suggests that this relationship may not be so simplistic (Gerald \& Oliver, 1993; Oliver, 1988).

2 I capitalize this term as a politicized reference to the nonhuman diaspora struggling under human supremacy. 
power. If free-riders are not contributing to mobilization but maintain the illusion of mass support, real power is reserved for core members and nonprofit leaders. This study considers that free-riding could be strategically cultivated in rationalized movements that value control.

\section{Materials and Methods}

To illustrate the strategic cultivation of free-riders in the nonprofit industrial complex, this paper will explore the phenomenon of flexitarianism in the professionalized Nonhuman Animal rights movement in the United States with a primary focus on Compassion Over Killing, Farm Animal Rights Movement (FARM), Farm Sanctuary, People for the Ethical Treatment of Animals (PETA), Mercy for Animals, and Vegan Outreach. Also known as vegetarianism, semivegetarianism, or reducetarianism, flexitarianism is defined as a consumption pattern that gravitates to vegetarianism but includes animal flesh and does not problematize non-food speciesism, such as using other animals for skin, hair, labor, forced reproduction, or test subjects (Derbyshire, 2016). It is a strategy favored by many nonprofits in the Nonhuman Animal rights movement, whereby organizations vie to "meet people where they are" to the effect of diminishing support for engaged activisms such as going vegan or participating in street protests (Wrenn, 2016a). As such, I define flexitarianism as a strategy that is characterized by incrementalism, appeals to self-interest, and has a hesitancy to define veganism as an end goal.

To avoid problematizing speciesist behaviors and alienating the public, nonprofits flip the script to appeal to existent behaviors believed to align with antispeciesist attitudes. Certainly, these organizations do sometimes advocate for veganism, but, generally, veganism is presented as only one of several options alongside flexitarian alternatives (Freeman, 2014; Wrenn, 2016a). Flexitarian frames allow a nonprofit to cast a wide net of resonance and combat stereotypes about anti-speciesism, but these frames also encourage free-riding if they fail to nudge the audience beyond existent attitudes and behaviors.

Nonprofits do not openly acknowledge the political motivations behind their decision-making and instead apply the rhetoric of practicality and efficacy in defense of chosen tactics and philosophies. As such, a review of social psychological research related to consumption and behavior change to test the alignment of practicality and efficiency with movement goals. To supplement this aim, 44 studies on vegan and vegetarian motivation were analyzed by me to demonstrate the strategic utility of flexitarianism. Although not all vegans support nonhuman liberation and not all nonhuman liberationists are vegan, most vegans eat plant-based out of concern for other animals 
(Lund, McKeegan, Cribbin, \& Sandøe, 2016). Therefore, vegan and liberationist identities will be explored jointly as they surface in the research.

\section{Results}

\section{Cognitive Dissonance and Consumption}

As one of the most fundamental theories related to behavior change, cognitive dissonance speaks to a misalignment between behavior and attitudes which creates discomfort. Theoretically, a social actor will seek to alleviate the discomfort by changing the behavior or creating rationalizations to mask the disconnect. In the case of consumption, there are many opportunities for cognitive dissonance to manifest because many social values are attached to food (clean eating is good, organic is good, greed is bad, fat is bad, suffering in the supply chain is bad, etc.) that run counter to behaviors encouraged by social environments (high cost of clean foods, better taste of unhealthy foods, inaccessibility of healthy foods, lack of transparency in food chain, etc.). As one example, many believe they eat considerably fewer calories than they actually do (Hill \& Davies, 2001; Lansky \& Brownell, 1982). This distortion is aggravated by the self-serving bias, which encourages persons to view themselves in a positive light and to think of themselves as more ethical than others (Miller \& Ross, 1975). In light of these tendencies, flexitarianism could be easily self-applied regardless of any behavior change undertaken. Consumers regularly fudge the truth to conform with social values.

When the discrepancies between attitudes and behaviors are challenged, it is also common to rationalize the misalignment to ease the tension. Vegan claimsmaking is frequently rebuffed by nonvegan claims that speciesist behaviors can and often do align with pro-animal attitudes (Colb, 2013). Some may insist, for instance, that they eat only who they kill (thus allowing their victims freedom of movement), while others may retort that they consume no "red meat" or drink only "organic milk." Social psychologist Melanie Joy (2010) explains that, when presented with the knowledge of violence and injustice inherent to nonhuman animal consumption, the disconnect between an individual's values (compassion, justice, and prosociality) and their behaviors (participation in speciesism) is brought into sharp relief, creating an intense feeling of discomfort. Flexitarianism can ease this dissonance by allowing those who continue to engage in nonveganism to reap the identity rewards of anti-speciesist pro-sociality, without necessarily having undergone any significant behavior change, if any at all. 


\section{Self-Interest and Prosociality}

Acknowledgement of a need or desire to change is only part of the battle; motivation to change is also key. Many nonprofits bank on the assumption that veganism is too threatening to self-interest to attract new adherents (Wrenn, 2016a), with flexitarianism acting as a more forgiving alternative that allows for the continued consumption of favored products. Nonprofits also promote flexitarianism to improve one's health (Freeman, 2014; Wrenn, 2016a). Appealing to health might increase support for flexitarianism, but it is less likely to increase support for veganism (presuming that nonprofits envision that flexitarianism will eventually lead to veganism). Research consistently demonstrates that individuals are less likely to go vegan (or vegetarian) and to remain so if they make the change for personal health reasons as opposed to prosocial ethical reasons (Cron \& Pobocik, 2013; Haverstock \& Forgays, 2012; Hoffman, Stallings, Bessinger, \& Brooks, 2013, Hussar \& Harris, 2010; Menzies \& Sheeshka, 2012).

The overwhelming majority of those who go vegan do so as an act of altruistic concern for other animals, not selfishness (Jannsen, Busch, Rödiger, \& Hamm, 2016; Lund et al., 2016). Because flexitarians are predominantly selforiented, they exhibit higher levels of disordered eating than vegans, as they alter their diet to change their own bodies, not to protect the bodies of others (Timko, Hormes, \& Chubski, 2012). Another consequence of avoiding the flesh of species considered "unhealthy" is that some flexitarians will increase their consumption of "meat" they perceive to be healthy, such as that from chickens and aquatic inhabitants (Technomic, 2015; Worsley \& Skrzypiec, 1998).

It is typical for nonprofits in the Nonhuman Animal rights movement to switch from politically-oriented anti-speciesism claimsmaking to individuallyfocused healthy lifestyle claimsmaking as they professionalize and moderate (Wrenn, 2016a). However, positioning veganism as a flexible dietary choice means that Nonhuman Animal products are still viewed positively as "treats" that are being deprived from the "standard" diet. Such a strategy supports, rather than challenges, prevailing negative stereotypes of veganism as ascetic and devoid of pleasure that Cole (2011) has identified in mainstream media. Framing veganism as sacrificial normalizes the consumption of nonhuman animals, just as framing non-smoking as sacrificial would normalize smoking. For Cole (2011), framing veganism as such creates a false dichotomy between taste and sacrifice: "... there is no reason to assume that aesthetic preferences for veg*an diets cannot and do not coincide with ethical choices" (p. 710). Semismoking and semi-vegetarianism are dissonant behaviors that only maintain this problematic of positive association. 
Alternatively, ethical incentives may assist users in quitting altogether by drawing on prosocial norms. To this effect, smoking campaigns that highlight the dangers of secondhand smoke, the polluting nature of tobacco butts, and the harm caused to Nonhuman Animals in cigarette testing have been employed. Likewise, the alternate claims to environmental sustainability and anti-speciesism provided by the nonhuman animal rights movement may be more effective motivational strategies than those that appeal to self-interest. Researchers emphasize that prosocial motivation decreases as personal incentives increase (Imam, 2014). In other words, campaigns that tap into prosocial norms while not overemphasizing personal gain will solicit a stronger response.

\section{Approach \#1: Incremental Behavior Change}

Theories of cognitive dissonance and prosociality suggest that the Nonhuman Animal rights movement underestimates the persuasion potential of its audience in relying on flexitarianism. The professionalized movement's hesitancy to discomfort its audience breaks in tradition with conventional aims of protest that target cognitive dissonance. Conventionally, a movement will identify the prosocial attitudes of its audience and emphasize that they are ill-aligned with problematic behaviors; the audience is expected to change its behavior to reduce the subsequent discomfort. Flexitarianism, however, nurtures the disconnect between attitudes and behaviors by suggesting that reducing one's consumption of Nonhuman Animal products (as opposed to avoiding them as much as is practical) is congruent with one's concern for the welfare of other animals.

To an extent, social movement organizations are right to concede that full abstention from animal products is inherently an incremental process, as nonvegan products are so ubiquitous and socially entrenched. Idealized "pure" veganism is, in practice, not fully achievable in a human-privileging society, and most vegans acknowledge this. Indeed, The Vegan Society defines veganism as a matter of practicality, not purity. ${ }^{3}$ While this practicality could be a site of congruence between radicals and moderates, professionalized organizations frequently reject veganism as a plausible goal based on the myth of vegan purity (Friedrich, n.d.; PETA, n.d.-a; Vegan Outreach, n.d.). Instead, they

3 The definition of veganism as defined by The Vegan Society:

"A philosophy and way of living which seeks to exclude-as far as is possible and practicable-[emphasis mine] all forms of exploitation of, and cruelty to, animals for food, clothing or any other purpose; and by extension, promotes the development and use of animal-free alternatives for the benefit of humans, animals and the environment."

See https://www.vegansociety.com/go-vegan/definition-veganism. 
concentrate heavily on reduction, potentially to the effect that it remains unclear where these incremental steps should lead. Rather than portraying flexitarianism as a stepping stone toward a vegan end, it becomes the end itself.

A brief analysis of veg starter guides produced by America's leading nonprofits supports this claim. Consider Farm Sanctuary's Something Better (2015), which refers almost exclusively to reducing flesh consumption meal by meal. Veganism is mentioned only once in the nine-page document in a quote provided by a celebrity athlete. Mercy for Animals' (n.d.) Vegetarian Starter Guide presents flexitarian options alongside veganism (which is never labeled as such), with the reader encouraged to view all options as equally important. Even then, the vegan option is presented last and it is heavily emphasized that "cheating" is okay. Likewise, FARM's (n.d.) Live Vegan Pledge presents veganism as one of several flexitarian options and refers readers to Mercy for Animals' starter guide for more information. Compassion Over Killing's (n.d.) Vegetarian Starter Guide promotes vegetarianism rather than veganism, primarily as a matter of choosing vegetarian foods "one bite at a time" rather than "becoming" vegetarian. PETA's (n.d.-b) Vegan Starter Kit is perhaps the only one to emphasize veganism by retaining the word "vegan" when describing vegan food and politics. Despite its heavy criticism of veganism, Vegan Outreach (2015) is another outlier. In its Guide to Cruelty-Free Eating, it advocates flexitarianism but notes that it can ease the transition into complete abstention.

\section{Approach \#2: Immediate Cessation}

Some organizations do advocate incrementalism in service of veganism, but social-psychological research on the "cutting back" method suggests potential complications for achieving behavior change. Again, the similarities between the consumption of tobacco and animal products is helpful. As is true of animal products, tobacco consumption is supported by strong social pulls and powerful institutional influences that encourage their continued use despite known negative health consequences. Anti-tobacco organizations, however, tend to promote the complete cessation of consumption rather than cutting back, as is preferred by anti-speciesist organizations. Indeed, some researchers emphasize that quitting smoking immediately is much preferable to incrementalism in terms of effectiveness. Consumer preference supports this approach as well. Most tobacco users favor a strategy of abrupt cessation over gradual cessation (Hughes, Callas, \& Peters, 2007). In one study, smokers who abruptly ceased use were twice as likely to be successful at quitting tobacco as those who gradually reduced their intake (Cheong, Yong, \& Borland, 2007). Researchers suggest that this discrepancy is explained by the psychological impact of maintaining problematic products as part of one's lifestyle. Once 
tobacco products are perceived to be in limited supply, they become precious. This preciousness supports a positive association with tobacco use.

In the case of animal products, flexitarianism is presented as a practical alternative to the presumed impossibility of veganism, but research challenges this point. One study comparing subjects assigned as vegan, vegetarian, flexitarian, or omnivore for the research period found that those assigned a vegan diet expressed no difference from omnivores in the acceptability of or adherence to the diet six months into the program (Moore, McGrievy, \& TurnerMcGrievy, 2015). Subsequently, the researchers advised that a plant-based diet would be more effective than recommending reductionism or moderation. While some of those recommended to go vegan did cheat, these participants were not any more likely to cheat than those assigned to other diets, and the positive results from their assigned veganism were far more dramatic than those who were allowed animal products. That is, if dieters are no less satisfied with a vegan diet, the potential for cheating is no higher with a vegan diet, and the health benefits of veganism are superior, then veganism will bring a greater positive return and should be recommended. For social movements, it may neither be possible nor of interest to police cheaters and micromanage individual embodiments of veganism; but advocating anything less than veganism will presumably elicit weaker results.

\section{Approach $\#_{3}$ Structured Incrementalism in Service of Veganism}

Thus far, I have argued that incrementalism runs counter to the psychology of effective behavior change, but additional research into tobacco cessation suggests that the maintenance of a clear end goal can increase the efficacy of incrementalism for some. One tobacco study finds that a scheduled reduction progressing to the eventual goal of complete cessation was most successful (Cinciripini, Lapitsky, Seay, Wallfisch, Kitchens, \& Van Vunakis, 1995). Structure works to reduce the fatigue and stress associated with behavior change, but it also improves feelings of self-efficacy. This could be useful for nonhuman animal rights organizations should they commit to positioning veganism as the objective and offer a scheduled and structured incremental program. Rather than framing nonvegan products as precious, they must be framed as obstacles along a path to new behavior and not left up to individual discretion and personal preference, as is the case with flexitarianism. The aforementioned analysis of veg starter guides finds little support for a structured path to a vegan end.

Another example surfaces in Vegan Outreach's Even If You Like Meat booklet campaign. The booklet explicitly avoids the terms "vegan" and "vegetarian," considering them to be barriers: "We believe that if people stop seeing the issue as 'all or nothing' (hence: nothing), we can break through their initial 
resistance.... Obviously we would love for everyone to go vegan and stay vegan. But just telling people to do so doesn't make it happen" (Vegan Outreach, 2004, p. 2). By appealing to the preciousness of "meat" and encouraging flexitarianism, Vegan Outreach hopes that audiences will make "humane choices." The exaltation of flexitarianism with vague definitions, loose boundaries, and no point of termination does little to impact behavior change. Considerable research supports this concern as evidenced in Table 1.

TABLE 1 Trends in flexitarianism

\begin{tabular}{|c|c|c|c|}
\hline Researchers & Demographic & Sample occurrence & Findings \\
\hline Brinkman et al. 2014 & $\begin{array}{l}\text { American West } \\
\text { university students }\end{array}$ & $\mathrm{N} / \mathrm{A}$ & $\begin{array}{l}\text { Less likely to endorse } \\
\text { ethical motivation } \\
\text { or activism, more } \\
\text { likely to exhibit } \\
\text { body shame than } \\
\text { vegetarians }\end{array}$ \\
\hline $\begin{array}{l}\text { De Backer \& } \\
\text { Hudders } 2015\end{array}$ & Flemish & $\mathrm{N} / \mathrm{A}$ & $\begin{array}{l}\text { Flexitarians are less } \\
\text { likely to support } \\
\text { anti-speciesist } \\
\text { charities }\end{array}$ \\
\hline Forestell et al. 2011 & $\begin{array}{l}\text { Female Psychology } \\
\text { university students } \\
\text { in Virginia }\end{array}$ & $\mathrm{N} / \mathrm{A}$ & $\begin{array}{l}\text { Flexitarians more } \\
\text { likely to display } \\
\text { disordered eating } \\
\text { than vegans }\end{array}$ \\
\hline Hoffman et al. 2013 & Americans & $\mathrm{N} / \mathrm{A}$ & $\begin{array}{l}\text { Flexitarians } \\
\text { concerned with } \\
\text { health less strict than } \\
\text { those concerned } \\
\text { with animal rights }\end{array}$ \\
\hline $\begin{array}{l}\text { Haverstock et al. } \\
2012\end{array}$ & $\begin{array}{l}\text { Current and } \\
\text { Former Flexitarian } \\
\text { Americans }\end{array}$ & $79 \%$ & $\begin{array}{l}\text { Currently limiting } \\
\text { animal products }\end{array}$ \\
\hline Hoek et al. 2004 & $\begin{array}{l}\text { Dutch non- } \\
\text { vegetarians who } \\
\text { regularly consume } \\
\text { meat substitutes }\end{array}$ & $\mathrm{N} / \mathrm{A}$ & $\begin{array}{l}\text { Do not hold strong } \\
\text { health, ecological, } \\
\text { or ethical ideologies; } \\
\text { similar to meat } \\
\text { eaters }\end{array}$ \\
\hline
\end{tabular}


TABLE 1 Trends in flexitarianism (cont.)

\begin{tabular}{|c|c|c|c|}
\hline Researchers & Demographic & Sample occurrence & Findings \\
\hline Juan et al. 2015 & $\begin{array}{l}\text { American } \\
\text { vegetarians }\end{array}$ & $48 \%$ & $\begin{array}{l}\text { Consume red meat } \\
\text { and/or seafood }\end{array}$ \\
\hline Latvala et al. 2012 & Finnish & $52 \%$ & $\begin{array}{l}\text { Identified as } \\
\text { flexitarian }\end{array}$ \\
\hline Lea $2001^{*}$ & South Australians & $21 \%$ & $\begin{array}{l}\text { Love to eat red meat, } \\
\text { including veal }\end{array}$ \\
\hline $\begin{array}{l}\text { Macdonald et al. } \\
2016\end{array}$ & Americans & $\mathrm{N} / \mathrm{A}$ & $\begin{array}{l}\text { No significant } \\
\text { differences between } \\
\text { those presented with } \\
\text { flexitarianism versus } \\
\text { veganism }\end{array}$ \\
\hline $\begin{array}{l}\text { Menzies \& } \\
\text { Sheeshka } 2012\end{array}$ & $\begin{array}{l}\text { Canadian } \\
\text { university students }\end{array}$ & $50 \%$ & $\begin{array}{l}\text { Flexitarians more } \\
\text { likely to recidivate if } \\
\text { reducing for health } \\
\text { reasons over animal } \\
\text { rights }\end{array}$ \\
\hline Plous 1991 & $\begin{array}{l}\text { DC-area animal } \\
\text { rights activists }\end{array}$ & $73 \% ; ~ 33 \%$ & $\begin{array}{l}\text { Nonvegans who } \\
\text { identified as } \\
\text { vegetarian or } \\
\text { semi-vegetarian; } \\
\text { consumed meat }\end{array}$ \\
\hline Plous 1998 & $\begin{array}{l}\text { DC-area animal } \\
\text { rights activists }\end{array}$ & $62 \%$ & $\begin{array}{l}\text { Nonvegans who } \\
\text { identified as } \\
\text { vegetarian or } \\
\text { semi-vegetarian; } \\
\text { consumed meat }\end{array}$ \\
\hline $\begin{array}{l}\text { Richardson et al. } \\
1993\end{array}$ & British & $28 \%$ & $\begin{array}{l}\text { Considered } \\
\text { themselves to be } \\
\text { reducing meat, } \\
\text { though only } 1 / 4 \text { of } \\
\text { these actually did }\end{array}$ \\
\hline Robinett $2012^{*}$ & Americans & $80 \% ; 13 \%$ & $\begin{array}{l}\text { Cut back for their } \\
\text { health; cut back for } \\
\text { animal cruelty }\end{array}$ \\
\hline
\end{tabular}


TABLE 1 Trends in flexitarianism (cont.)

\begin{tabular}{|c|c|c|c|}
\hline Researchers & Demographic & Sample occurrence & Findings \\
\hline Rothgerber 2012 & $\begin{array}{l}\text { Psychology } \\
\text { university students } \\
\text { in Kentucky }\end{array}$ & $\mathrm{N} / \mathrm{A}$ & $\begin{array}{l}\text { Women underreport } \\
\text { "meat" consumption }\end{array}$ \\
\hline Rothgerber 2014 & Americans & $\mathrm{N} / \mathrm{A}$ & $\begin{array}{l}\text { Flexitarians far } \\
\text { less strict and less } \\
\text { concerned about } \\
\text { animal ethics }\end{array}$ \\
\hline Rothgerber 2015 & General & $\mathrm{N} / \mathrm{A}$ & $\begin{array}{l}\text { Vegetarians more } \\
\text { likely to violate } \\
\text { diet and less } \\
\text { ethically concerned, } \\
\text { committed to animal } \\
\text { rights, and bothered } \\
\text { by meat than vegans }\end{array}$ \\
\hline Ruby 2011 & Westerners & $\mathrm{N} / \mathrm{A}$ & $\begin{array}{l}\text { No consensus over } \\
\text { the meaning of } \\
\text { vegetarianism }\end{array}$ \\
\hline Ruby et al. 2013 & $\begin{array}{l}\text { Americans and } \\
\text { Indians }\end{array}$ & $\mathrm{N} / \mathrm{A}$ & $\begin{array}{l}\text { Westerners prioritize } \\
\text { concern with animal } \\
\text { welfare; Indians } \\
\text { prioritize purity }\end{array}$ \\
\hline Stahler 2011* & Americans & $33 \%$ & $\begin{array}{l}\text { Eat vegetarian } \\
\text { meals regularly and } \\
\text { could be considered } \\
\text { flexitarian }\end{array}$ \\
\hline Technomic $2015^{*}$ & Americans & $72 \%$ & $\begin{array}{l}\text { Flexitarians reported } \\
\text { increased "seafood" } \\
\text { purchases but found } \\
\text { vegan foods just as } \\
\text { satisfying }\end{array}$ \\
\hline Timko et al. 2012 & $\begin{array}{l}\text { Psychology } \\
\text { university students } \\
\text { in Pennsylvania }\end{array}$ & $\mathrm{N} / \mathrm{A}$ & $\begin{array}{l}\text { Flexitarians scored } \\
\text { higher in disordered } \\
\text { eating than vegans }\end{array}$ \\
\hline $\begin{array}{l}\text { Voucher Codes Pro } \\
2015^{*}\end{array}$ & $\begin{array}{l}\text { British vegetarian } \\
\text { alcohol consumers }\end{array}$ & $33 \%$ & $\begin{array}{l}\text { Consumed meat } \\
\text { under the influence }\end{array}$ \\
\hline
\end{tabular}




\begin{tabular}{|c|c|c|c|}
\hline Researchers & Demographic & Sample occurrence & Findings \\
\hline $\begin{array}{l}\text { Worsley \& } \\
\text { Skrzypiec } 1998\end{array}$ & $\begin{array}{l}\text { South Australian } \\
\text { secondary school } \\
\text { students }\end{array}$ & $37 \%$ girls; $12 \%$ boys & $\begin{array}{l}\text { Ate less red meat but } \\
\text { more chicken }\end{array}$ \\
\hline
\end{tabular}

* Not peer reviewed.

\section{Discussion}

\section{Flexitarianism and Veganism at Odds}

Critical psychological research on consumption and persuasion demonstrates the weaknesses of an unstructured incremental approach framed to appeal to self-interest. This section will explain research on the specifics of flexitarianism and veganism. When pressed by critics in the social movement space, nonprofits defend flexitarianism as a necessary compromise that is ultimately in alignment with veganism (Wrenn, 2016a). Research, however, confounds this assumption (Table 1). Many who identify as flexitarian do not significantly reduce their intake of animal products. The reasons for this are many. For one, many people already identify as flexitarian (Dagevos \& Voordouw, 2013) prior to social movement intervention, as the term easily applies to anyone who eats the occasionally low-flesh or flesh-free meal. The Nonhuman Animal rights movement is not the only promoter of plant-based eating, and, although veganism is stigmatized, eating more fruits and vegetables is a social value. Adding to this is the movement's effort to normalize flexitarianism as valuable and good, making it easier for individuals to apply to their existing behaviors to capitalize on the positive associations of a flexitarian identity.

Indeed, the meaning of flexitarianism is highly subjective (Ruby, 2011). For instance, many who identify as vegetarian continue to eat "meat" (Menzies \& Sheeshka, 2012). Gender, nationality, and other identities can also skew selfidentification (Rothgerber, 2012; Ruby, Heine, Kamble, Cheng, \& Waddar, 2013). One study reports that participants who self-identified as semi-vegetarian consumed more animal products than those who did not (Worsley \& Skrzypiec, 1998). Many do not even view chickens or fishes as sources of "meat" and thus do not recognize any contradiction from consuming their flesh while also identifying as vegetarian. Given this widespread confusion, if professionalized 
anti-speciesism mobilization is having any impact at all, it could simply be popularizing low impact (or no impact) flexitarianism as an ideological matter, with audiences adopting the positive label without adopting the behavior change.

When bystanders collect on the positive identity promulgated by a social movement without incurring the changes, costs, or risks associated with participation, this constitutes free-riding. One survey found that one out of three Americans can be considered flexitarian (Stahler, 2011), while another found that $37 \%$ at least sometimes eat vegetarian meals when dining out (Vegetarian Resource Group, 2016). While these figures suggest the cultural normalization of plant-based eating, there is little evidence to support that these flexitarians are also anti-speciesism activists with vegan aspirations.

\section{Professionalization and the Nonprofit Industrial Complex}

A free-rider is one who reaps the benefits of a movement's progress without having participated to help achieve that progress. A free-rider might also identify with positive or rewarding movement identities without engaging in meaningful activism necessary to substantiate these identities. Although extremely shallow, support of this kind may indicate movement success in that the activist identity has been normalized and popularized. Some movement theorists insist that manifesting a collective identity is a movement's most critical goal, as it can manifest into the everyday behaviors of participants (Melucci, 1995). However, Garfinkel's (1967) ethnomethodological research suggests that social actors draw on social norms to explain and assign meaning to their selves and behavior. Identity is reflexive and situational and may or may not align with objective reality. To social movements, mainstreamed identity, if detached from progress toward goals, may represent a co-optation of meaning.

This phenomenon plagues many, if not most, movements. As feminism takes to the mainstream, for instance, more bystanders in the movement's audience identify as feminist without having engaged in feminist agitation. Of course, the normalization of the feminist identity is in some ways a gain, but some scholars worry that the feminist identity is simply attached to traditionally sexist or patriarchal behaviors (Levy, 2005; Zeisler, 2016). As sociologist Michael Kimmel (2008) explains: "... they want all the rights, but resist the collective action that is required to achieve them" (p. 264). The dissemination of a diluted and depoliticized activist identity is not necessarily congruent with movement success. By way of an example, a study of localized environmental activism sparked by a nuclear leak found that only $12 \%$ of community members sampled who supported the movement's aim actually donated time, money, or other resources (Walsh \& Warland, 1983). 
More recently, debate has also swirled around the role of social media activism, as the more laborious work of offline structural work such as lobbying and policy making is eclipsed by the more easily engaged and less risky behavior of "liking" or sharing stories and images (Tufekci, 2014). Disengaged identification has the potential to disrupt movement solidarity. Subsequently, it decreases the movement's ability to retain membership, access resources, and enact change. Within social movement spaces, networks interact with identity and these ties bind. They counter risk aversion and predict future participation (McAdam, 1986). Free-riding, it follows, could undermine this vital movement resource.

The changing face of American movements is not a product of happenstance; the devaluation of activism is a result of larger political forces in the social movement arena. Professionalized organizations nurture paid membership over protest in an attempt to stabilize and rationalize operations (McCarthy \& Zald, 1973). While paid membership is an important resource for social movements, fundraising and social change are not always in alignment, as fundraising requires a considerable moderation in goals to appeal to the largest audience and appease state and elite interests (Rodríguez, 2007; Staggenborg, 1988). Radical social change efforts become unappealing to professionalized organizations, as they risk alienating their support system. In fact, the government is responsible for about a third of American nonprofit revenue (McKeever, 2015), and elite donors and foundations contribute sizable portions as well. This nonprofit industrial complex subsequently pressures nonprofits to support ideologies that are already consistent with prevailing political or cultural sentiment and solutions that are already compatible with current systems. Rather than shaping society to adapt to the movement's proposed reality, the movement itself undergoes change by adapting to existent reality.

\section{The Campaign to Villainize Veganism}

The prioritization of fundraising and reforms over restructuring is one explanation as to why flexitarianism is preferred to veganism. It also lends evidence as to why veganism is not simply downplayed but is often villainized. Veganism is a position which understands the cessation of animal use as most consistent with the goal of Nonhuman Animal liberation and is favored by radical factions; but professionalized nonprofits frequently paint it as elitist, impossible, too restrictive or rigorous, unhappy, and ineffectual (Wrenn, 2016a). Instead, cutting back on flesh consumption or switching to "humanely-raised" products is championed over efforts for total liberation (Garner, 2013). "Membership" 
is relegated to monthly or annual donations, and veganism is obscured so as not to disrupt the movement's goal of casting a wide net of shared identity to encourage superficial activism. Only about 1 to $2 \%$ of the American population is vegan (mostly for political reasons) but recall that as many as $37 \%$ identify as flexitarian (mostly for health reasons) (Vegetarian Resource Group, 2016). This would presumably present an incentive to organizations to appeal to the larger, apolitical demographic.

Furthermore, most individuals feel some concern for Nonhuman Animal welfare and thus present an even larger potential support for the Nonhuman Animal rights movement (Faunalytics, 2016), but few understand how to operationalize this attitude (Prunty \& Apple, 2013). This ignorance sees anti-speciesist organizations in a powerful position to develop solutions and manipulate public awareness in ways that are self-serving. Professionalized organizations are free to tap into pre-existing moral concerns to extract resources without motivating significant behavior change. Professionalized campaigns promote flexitarianism as easier, more accessible, and less socially alienating than the vegan alternative (the very alternative that is unavoidably necessary to realize nonhuman animal liberation) by framing veganism as puritanical or elitist.

Vegan Outreach, for instance, regularly releases polemics designed to rebuff the importance of veganism. In one such essay, cofounder Matt Ball describes vegans as "angry," "arrogant," "belligerent," "crazy," "dogmatic," "impotent," "misanthropic," "obsessive," hateful, and psychologically unsound individuals who "... draw self-worth from being apart from and superior to the rest ..." (2012). He further insists that these vegans feed "a negative stereotype" and waste the time of "practical, forward-looking advocates." Flexitarianism, however, "meets people where they are," and more importantly, it does not alienate donors (Wrenn, 2016a).

Ball has reason to be concerned about the security of his organization given the overwhelmingly negative portrayal of veganism in the media (Cole \& Morgan, 2011). In a bid to distance themselves from these stereotypes and increase resonance, professional organizations only replicate these disparagements. The strategy of "meeting people where they are" is also evidenced in The Vegan Society's Love Vegan campaign in which various posters suggest that "You don't have to be vegan to ..." consume vegan food, cosmetics, and clothing. The society dubbed this an "incremental" approach to veganism and attributed a spike in membership growth to the campaign (The Vegan Society, 2014). However, the posters assure audiences that veganism is not necessary, which suggests that the Society's approach is but a variant of incrementalism that is not supported by social psychological research. 
Villainizing or invisibilizing veganism in a society that normalizes nonhuman animal consumption can be disastrous for Nonhuman Animals and highly profitable for speciesist industries. Research indicates that when "meat" products are flourished with high welfare descriptions, consumers show a much stronger preference for the products, even if the products are falsely labeled and the perceived differences are imagined. They are willing to pay more, and, most importantly, they consume more than they otherwise would (Anderson \& Barrett 2016). For that matter, they are not especially committed to supporting higher welfare for nonhumans. Psychologist Hank Rothgerber (2015) explains, "... following a diet that includes animals may produce dissonance pressures to hold unfavorable attitudes toward these animals" (p. 202). Going vegan, he finds, produces stronger adherence to anti-speciesist attitudes.

Producers, meanwhile, are aware of the profitability of high welfare rhetoric and its ability to curb vegetarianism, and they are eager to tap into "humane" ideology to increase sales (Henchion, McCarthy, Resconi, \& Troy, 2014). The failure to advocate clearly and consistently for veganism allows a measure of protection for speciesist industries, while the popularization of depoliticized flexitarianism could even contribute to the strengthening of these industries should it contribute to increased sales and more confident consumers.

\section{Conclusion}

Individual and societal behavioral changes are difficult to realize. As was explored herein, institutions, culture, and ideologies carve paths of least resistance that may ease social cohesiveness and functioning, but, in doing so, also reduce the potential for change and innovation. These barriers are especially acute for movements which aim to create new behavioral pathways and social meanings. Free-riders may represent a superficial, if wide-reaching, cultural congruency with a movement's goals, but they ultimately fail to provide concrete support in terms of political activity, critical consciousness, or even consumption changes. The shallow identity that is fabricated by a mass of individuals who undertake little to no behavioral change is not only insufficient for manifesting lasting social change but can even impede it by deforming movement aims.

Furthermore, it was argued that an uncritical mass of individual consumers is a protective measure that is encouraged by the state and industries through a nonprofit industrial complex. A political collective can be thwarted or otherwise disempowered by the dominance of free-riders such that nonprofits financially dependent upon elites for survival may actively nurture inactive supporters. Like free-riders, organizations also behave rationally, opting for 
a low-cost, low-risk state of well-being over radical engagement. Free-riders come to exist as a large pool of indirect support for the professionalized nonprofit model. It is precisely their disconnectedness that becomes advantageous. Actively cultivated free-riding involves participation with flexible identities and detached donating. The burden of social change work is subsequently concentrated and protected in the hands of a select few nonprofit elites. This process of disempowerment, bureaucratization, and redirection of power from the many to the few is tied to the neoliberal state's efforts to dismantle threatening grassroots activism and the potential for mass protest (Rodríguez, 2007).

With movement organizations hesitant to make clear claims as to appropriate political actions, preexistent behaviors can be reimagined as consistent with protest goals. In the era of neoliberalism, free-riders are transformed from burden to boon in a professionalized movement space that understands democratic decision-making to be a threat. An uncritical mass is no longer problematic but profitable. Free-riders reap the rewards of a do-gooder activist identity without incurring the costs of participation, while the nonprofit industrial complex's economic logic of growth remains intact.

Despite the common nonprofit appeal to practicality, existing research, limited though it may be, demonstrates that the motivation to go vegan and stay vegan can be activated without resorting to the promotion of dead-end flexitarianism. This article outlined three paths to consumptive behavior change identified in the literature: full and immediate cessation, unstructured incrementalism, and structured incrementalism with a clearly defined end goal. Research supported the effectiveness of the direct and abrupt cessation approach as well as the structured incremental approach, but not the unstructured incremental approach most often promulgated by nonprofits. Research also suggests that veganism can be encouraged and sustained more effectively by providing education and support networks, and by appealing to prosociality in addition to the standard health focus. These recommendations are summarized in Table 2.

Some limitations to this research discussed herein warrant mention. First, most vegan motivation research does not conceptualize veganism as a political position but rather as diet, and subsequently, it does not examine how other non-food animal products might also be eliminated from consumption patterns. Second, a number of the studies identified as successful draw on intensive programs that transpired over a number of weeks. Investing in programs of such intensity is costly and the least realistic for budget-minded nonprofits. However, their higher success rate indicates that supporting systemic-level interventions through universities, community social services, and local activist collectives would be a worthy investment. 
TABLE 2 Recommendations for adopting plant-based diets

\begin{tabular}{|c|c|c|c|}
\hline Researchers & Demographic & Barrier & Recommendation \\
\hline $\begin{array}{l}\text { Bastian \& } \\
\text { Loughnan } 2016\end{array}$ & General & Dissonance & $\begin{array}{l}\text { Educate about viable } \\
\text { alternatives }\end{array}$ \\
\hline $\begin{array}{l}\text { Faver \& } \\
\text { Schiefelbein } 2014\end{array}$ & $\begin{array}{l}\text { Social Worker } \\
\text { students near US/ } \\
\text { Mexico border }\end{array}$ & $\begin{array}{l}\text { Dining out and } \\
\text { social events }\end{array}$ & $\begin{array}{l}\text { Nurture higher } \\
\text { commitment } \\
\text { attitudes, greater } \\
\text { family support, and } \\
\text { intensive educational } \\
\text { programs }\end{array}$ \\
\hline Flynn et al. 2013 & $\begin{array}{l}\text { Low-income Rhode } \\
\text { Islanders }\end{array}$ & $\begin{array}{l}\text { Nutritional } \\
\text { knowledge }\end{array}$ & $\begin{array}{l}\text { Intensive cooking } \\
\text { program, increased } \\
\text { plant-based eating, } \\
\text { and decreased food } \\
\text { insecurity }\end{array}$ \\
\hline $\begin{array}{l}\text { Galvin \& Herzog } \\
1992\end{array}$ & American activists & $\begin{array}{l}\text { Idealism and } \\
\text { gender norms }\end{array}$ & $\mathrm{N} / \mathrm{A}$ \\
\hline $\begin{array}{l}\text { Gaziano \& Lewis } \\
2013\end{array}$ & $\begin{array}{l}\text { American } \\
\text { Buddhists }\end{array}$ & Ignorance & Humane education \\
\hline $\begin{array}{l}\text { Haverstock et al. } \\
2012\end{array}$ & $\begin{array}{l}\text { Current and } \\
\text { former flexitarian } \\
\text { Americans }\end{array}$ & Isolation & $\begin{array}{l}\text { Increase group } \\
\text { identity and } \\
\text { networking }\end{array}$ \\
\hline Hepting et al. 2013 & Canadians & Information & $\begin{array}{l}\text { Informational } \\
\text { software and } \\
\text { communication } \\
\text { technology }\end{array}$ \\
\hline Herzog 2007 & Meta-analysis & Gender norms & $\mathrm{N} / \mathrm{A}$ \\
\hline Herzog et al. 1991 & $\begin{array}{l}\text { North Carolinian } \\
\text { college students }\end{array}$ & Gender norms & $\mathrm{N} / \mathrm{A}$ \\
\hline Hoek et al. 2004 & Dutch & $\begin{array}{l}\text { Disinterest in } \\
\text { health or ecological } \\
\text { themes }\end{array}$ & $\begin{array}{l}\text { Promote meat } \\
\text { substitutes using } \\
\text { nutritional arguments, } \\
\text { but also ecological } \\
\text { arguments }\end{array}$ \\
\hline Janssen et al. 2016 & Germans & Motivation & $\begin{array}{l}\text { Animal rights } \\
\text { message, but also } \\
\text { a multi-pronged } \\
\text { message }\end{array}$ \\
\hline
\end{tabular}


TABLE 2 Recommendations for adopting plant-based diets (cont.)

\begin{tabular}{|c|c|c|c|}
\hline Researchers & Demographic & Barrier & Recommendation \\
\hline Lea $2001^{*}$ & South Australians & $\begin{array}{l}\text { Nutritional } \\
\text { information }\end{array}$ & $\begin{array}{l}\text { Tailored information } \\
\text { focusing on nutrition, } \\
\text { but also ethical } \\
\text { considerations }\end{array}$ \\
\hline Moore et al. 2015 & Fat Americans & Dietary preference & $\begin{array}{l}\text { No variation in } \\
\text { food preference } \\
\text { between vegans } \\
\text { and flexitarians, } \\
\text { recommends } \\
\text { veganism as it has } \\
\text { highest health impact }\end{array}$ \\
\hline Shapiro 1994 & $\begin{array}{l}\text { Animal rights } \\
\text { activists }\end{array}$ & $\begin{array}{l}\text { Resistance to } \\
\text { animal suffering }\end{array}$ & $\begin{array}{l}\text { Increase knowledge } \\
\text { of suffering; healthy } \\
\text { copying techniques } \\
\text { for uncomfortable } \\
\text { knowledge }\end{array}$ \\
\hline $\begin{array}{l}\text { Rothgerber \& } \\
\text { Mican } 2014\end{array}$ & $\begin{array}{l}\text { American and } \\
\text { Indian }\end{array}$ & Empathy & $\begin{array}{l}\text { Childhood pet } \\
\text { attachment increases } \\
\text { propensity for "meat" } \\
\text { avoidance }\end{array}$ \\
\hline $\begin{array}{l}\text { Vegan Society } \\
2016^{*}\end{array}$ & British & Geographic access & $\begin{array}{l}\text { Positive media } \\
\text { coverage }\end{array}$ \\
\hline $\begin{array}{l}\text { Vinnari \& Vinnari } \\
2014\end{array}$ & Westerners & $\begin{array}{l}\text { Nutritional } \\
\text { concerns, cost, } \\
\text { cultural identity, } \\
\text { speciesism, } \\
\text { ignorance }\end{array}$ & $\begin{array}{l}\text { Transition with } \\
\text { identification of } \\
\text { objectives and } \\
\text { obstacles; government } \\
\text { support }\end{array}$ \\
\hline $\begin{array}{l}\text { Wansink et al. } \\
2014\end{array}$ & $\begin{array}{l}\text { Non-vegetarian } \\
\text { and non-Asian } \\
\text { American women }\end{array}$ & $\begin{array}{l}\text { Preconceptions } \\
\text { about taste, ease of } \\
\text { preparation, and } \\
\text { perishability }\end{array}$ & $\begin{array}{l}\text { Dispel misconceptions } \\
\text { rather than focus on } \\
\text { nutrition }\end{array}$ \\
\hline $\begin{array}{l}\text { Wiig \& Smith } \\
2008\end{array}$ & $\begin{array}{l}\text { Low-income } \\
\text { Minnesotan } \\
\text { women }\end{array}$ & Access & $\begin{array}{l}\text { Educate about } \\
\text { budgeting, nutrition, } \\
\text { and meal preparation }\end{array}$ \\
\hline
\end{tabular}

* Not peer reviewed. 


\section{Acknowledgments}

The author would like to thank Jacqueline Adamescu, who assisted with the first draft of this manuscript.

\section{References}

Adams, C. (2003).The pornography of meat. New York, NY:The Continuum International Publishing Group, Inc.

Anderson, E., \& Barrett, L. (2016). Affective beliefs influence the experience of eating meat. PLoS One, 11(8), e0160424. DoI: 10.1371/journal.pone.0160424.

Armstrong, E. (2002). Forging gay identities. Chicago, IL: University of Chicago Press.

Ball, M. (2012). Politics, personal conduct, and the vegan police. Retrieved November 1, 2016, from http://whyveganoutreach.blogspot.com/2012/11/looking-forward-recentlypublished-in.html.

Bastian, B., \& Loughnan, S. (2016). Resolving the meat-paradox. Personality and Social Psychology Review, 21(3), 278-299. DOI: 10.1177/1088868316647562.

Bongiorno, R., Bain, P., \& Haslam, N. (2013). When sex doesn't sell. PLoS One, 8(12), e83311. DOI: 10.1371/journal.pone.0083311.

Brinkman, B., Khan, A., Edner, B., \& Rosén, L. (2014). Self-objectification, feminist activism and conformity to feminine norms among female vegetarians, semivegetarians, and non-vegetarians. Eating Behaviors, 15(1), 171-174. DoI: 10.1016/j. eatbeh.2013.11.006.

Cheong, Y., Yong, H., \& Borland, R. (2007). Does how you quit affect success? Nicotine \& Tobacco Research, 9(8), 801-810. DOI: 10.1080/14622200701484961.

Cinciripini, P., Lapitsky, L., Seay, S., Wallfisch, A., Kitchens, K., \& Van Vunakis, H. (1995). The effects of smoking schedules on cessation outcome. Journal of Consulting Psychology, 63(3), 388-399.

Colb, S. (2013). Mind if I order the cheeseburger? Brooklyn, NY: Lantern Books.

Cole, M. (2011). Asceticism and hedonism in research discourses of veg*anism. British Food Journal, no(7), pp. 706-716.

Cole, M., \& Morgan, K. (2011). Veganphobia. The British Journal of Sociology, 62(1), 134-153.

Compassion Over Killing. (n.d.). Vegetarian starter guide. Washington, DC: Compassion Over Killing.

Cron, J., \& Pobocik, R. (2013). Intentions to continue vegetarian dietary patterns.Journal of the Academy of Nutrition and Dietetics, 113(9), A90. DoI: 10.1016/j.jand.2013.06.317.

Dagevos, H., \& Voordouw, J. (2013). Sustainability and meat consumption. Sustainability, $9(2), 60-69$. 
De Backer, C., \& Hudders, L. (2015). Meat morals. Meat Science, 99, 68-74. DoI: 10.1016/j .meatsci.2014.08.011.

Deckha, M. (2008). Disturbing images. Ethics and the Environment, 13(2), 35-76.

Derbyshire, E. (2016). Flexitarian diets and health: A review of the evidence-based literature. Frontiers in Nutrition, 3(55). DoI: 10.3389/fnut.2016.00055.

Friedrich, B. (n.d.) Effective advocacy. Retrieved August 6, 2017, from https://ccc.farm sanctuary.org/be-a-better-advocate/read-essays-and-books/effectiveadvocacy/

Garfinkel, H. (1967). Studies in ethnomethodology. Cambridge, UK: Polity Press.

Greenebaum, J. (2016). Questioning the concept of vegan privilege. Humanity \& Society, 41(3), 355-372. DOI: 10.1177/0160597616640308.

Haverstock, K., \& Forgays, D. (2012). To eat or not to eat. Appetite, 58(3), 1030-1036. DoI: 10.1016/j.appet.2012.02.048.

Henchion, M., McCarthy, M., Resconi, V., \& Troy, D. (2014). Meat consumption. Meat Science, 98, 561-568. DOI: 10.1016/j.meatsci.2014.06.007.

Hepting, D., Jaffe, J., \& Maciag, T. (2014). Operationalizing ethics in food choice decisions. Journal of Agricultural and Environmental Ethics, 27(3), 453-469. DOI: 10.1007/ s10806-013-9473-8.

Herzog, H. (2007). Gender differences in human-animal interactions. Anthrozoös, 2o(1), 7-21.

Herzog, H., Betchart, N., \& Pittman, R. (1991). Gender, sex role orientation, and attitudes toward animals. Anthrozoös, 4(3), 184-191.

Hill, R., \&. Davies, P. (2001). The validity of self-reported energy intake as determined using the doubly labelled water technique. British Journal of Nutrition, 85(4), 415-430.

Hoek, A., Luning, P., Stafleu, A., \& de Graaf, C. (2004). Food-related lifestyle and health attitudes of Dutch vegetarians. Appetite, 42(3), 265-272. DoI: 10.1016/j.appet .2003.12.003.

Hoffman, S., Stallings, S., Bessinger, R., \& Brooks, G. (2013). Differences between health and ethical vegetarians. Appetite, 65, 139-144. DOI: 10.1016/j.appet.2013.02.009.

Hughes, J., Callas, P., \& Peters, E. (2007). Interest in gradual cessation. Nicotine \& Tobacco Research, 9(6), 671-675. DOI: 10.1080/14622200701365293.

Humane Research Council. (2007). Advocating meat reduction and vegetarianism to adults in the U.S. Seattle, WA: Humane Research Council.

Hunt, S., \& Benford, R. (2004). Collective identity, solidarity, and commitment. In D. Snow, S. Soule, \& H. Kriesi (Eds.), The Blackwell companion to social movements (pp. 433-458). Oxford, UK: Blackwell Publishing.

Hussar, K., \& Harris, P. (2010). Children who choose not to eat meat. SocialDevelopment, 19(3), 627-641. DOI: 10.1111/j.1467-9507.2009.00547.x.

Imas, A. (2014). Working for the "warm glow". Journal of Public Economics, 114 (June), 14-18. DOI: 10.1016/j.jpubeco.2013.11.006.

FARM. (n.d.). Live vegan pledge. Retrieved May 2, 2018, from http://org2.salsalabs .com/o/7379/p/salsa/web/common/public/signup?signup_page_KEY=7495. 
Farm Sanctuary. (2015). Something better. Watkin's Glen, NY: Farm Sanctuary.

Faunalytics. (2016). Animal tracker 2016. Retrieved November 1, 2016, from https:// faunalytics.org/animal-tracker-2016-contradictions-in-public-opinion/.

Faver, C., \& Schiefelbein, T. (2014). A program to increase dietary consumption of plant-based foods among university students. Food Studies, 3(3), 57-63. Dor: 10.18848/2160-1933/CGP/vo3io3/40580.

Food and Agriculture Organization of the United Nations. (2013). FAOSTATProduction, livestock primary. Retrieved November 1, 2016, from http://faostat.fao. org/site/569/DesktopDefault.aspx?PageID=569\#ancor.

Forestell, C., Spaeth, A., \& Kane, S. (2012). To eat or not to eat red meat. Appetite, 58(2), 319-325. DOI: 10.1016/j.appet.2011.10.015.

Flynn, M., Relnert, S., \& Schiff, A. (2013). A six-week cooking program of plantbased recipes improves food security, body weight, and food purchases for food pantry clients. Journal of Hunger \& Environmental Nutrition, 8(1), 73-84. DOI: 10.1080/19320248.2012.758066.

Freeman, C. (2014). Framing farming. New York, NY: Rodopi.

Friedman, D., \& McAdam, D. (1992). Collective identity and activism. In A. Morris \& C. Mueller (Eds.), Frontiers of social movement theory (pp. 156-173). New Haven, CT: Yale University Press.

Gaarder, E. (2011). Women and the animal rights movement. New Brunswick, NJ: Rutgers University Press.

Galvin, S., \& Herzog, H. (1992). Ethical ideology, animal rights activism, and attitudes toward the treatment of animals. Ethics \& Behavior, 2(3), 141-149.

Garner, R. (2013). A theory of justice for animals. New York, NY: Oxford University Press.

Gaziano, J., \& Lewis, J. (2013). All beings are equal but some are more equal than others: Buddhism and vegetarianism in the U.S. Western Buddhist Review, 6, 58-77.

Glasser, C. (2011). Tied oppressions. The Brock Review, 12(1), 51-68. DoI: 10.26522/ br.v12i1.333.

Jannsen, M., Busch, C., Rödiger, M., \& Hamm, U. (2016). Motives of consumers following a vegan diet and their attitudes towards animal agriculture. Appetite, 105, 643651. DOI: 10.1016/j.appet.2016.06.039.

Joy, M. (2010). Why we love dogs, eat pigs, and wear cows. Newburyport, MA: Conari Press.

Juan, W., Yamini, S., \& Britten, P. (2015). Food intake patterns of self-identified vegetarians among the U.S. population, 2007-2010. Procedia Food Science, 4, 86-93. DoI: 10.1016/j.profoo.2015.06.013.

Kimmel, M. (2008). Guyland. New York, NY: HarperCollins.

Lansky, D., \& Brownell, K. (1982). Estimates of food quantity and calories. American Journal of Clinical Nutrition, 35(4), 727-732. 
Latvala, T., Niva, M., Mäkelä, J., Pouta, E., Heikkilä, J., Kotro, J., \& Forsman-Hugg, S. (2012). Diversifying meat consumption patterns. Meat Science, 92(1), 71-77. DOI: 10.1016/ j.meatsci.2012.04.014.

Lea, E. (2001). Moving from meat, Unpublished thesis. University of Adelaide: Adelaide, AU.

Levy, A. (2005). Female chauvinist pigs. New York, NY: Free Press.

Lund, T., McKeegan, D., Cribbin, C., \& Sandøe, P. (2016). Animal ethics profiling of vegetarians, vegans and meat-eaters. Anthrozoös, 29(1), 89-106. DoI: 10.1080/08927936.2015.1083192.

Macdonald, B., Caldwell, K., \& Boese, G. (2016). The effects of 'reduce' and 'eliminate' appeals on individual meat consumption. Reducetarian Foundation.

Marwell, G., \& Oliver, P. (1993). The critical mass in collective action. Cambridge, MA: Cambridge University Press.

McAdam, D. (1986). Recruitment to high-risk activism. American Journal of Sociology, 92(1), pp. 64-9o.

McCarthy, J., \& Zald, M. (1973). The trend of social movements in America. Morristown, NJ: General Learning Press.

McKeever, B. (2015). The nonprofit sector in brief 2015. Washington, DC: The Urban Institute.

Melucci, A. (1995). The process of collective identity. In H. Johnston \& B. Klandermans (Eds.), Social movements and culture (pp. 41-63). New York, NY: Routledge.

Menzies, K., \& Sheeshka, J. (2012). The process of exiting vegetarianism. Canadian Journal of Dietetic Practice and Research, 73(4), 163-168. Do I: 10.3148/73.4.2012.163.

Mercy for Animals. (n.d.). The vegetarian starter guide. Los Angeles, CA: Mercy for Animals.

Meyer, D., Whittier, N., \& Robnett, B. (2002). Social movements. New York, NY: Oxford University Press.

Miller, D., \& Ross, M. (1975). Self-serving biases in the attribution of causality. Psychological Bulletin, 82(2), 213-225.

Moore, W., McGrievy, M., \& Turner-McGrievy, G. (2015). Dietary adherence and acceptability of five different diets, including vegan and vegetarian diets, for weight loss: the new DIETs study. Eating Behaviors, 19, 33-38. DoI: 10.1016/j.eatbeh.2015.06.011.

Newport, F. (2012). In U.S., 5\% consider themselves vegetarians. Retrieved November 1 , 2016, from http://www.gallup.com/poll/156215/Consider-Themselves-Vegetarians. aspx.

Oliver, P. (1988). The paradox of group size in collective action. American Sociological Review, 53(1), 1-8.

Olson, M. (1968). The logic of collective action. Cambridge, MA: Harvard University Press. 
PETA. (n.d.-a). A note about small amounts of animal products in foods. Retrieved August 6, 2017, from https://www.peta.org/living/food/making-transition-vegetarian/ ideas-vegetarian-living/tiny-amount-animal-products-food/.

PETA. (n.d.-b). Vegan starter kit. Norfolk, VA: PETA.

Plous, S. (1991). An attitude survey of animal rights activists. Psychological Science, 2(3), 194-196.

Plous, S. (1998). Signs of change within the animal rights movement. Journal of Comparative Psychology, 112(1), 48-54.

Prunty, J., \& Apple, K. (2013). Painfully aware. Anthrozoös, 26(2), 265-278.

Richardson, N., Shepherd, R., \& Elliman, N. (1993). Current attitudes and future influences on meat consumption in the U.K. Appetite, 21(1), 41-51.

Robinett, S. (2012). Meet the flexitarian. Retrieved November 1, 2016, from http://ww1 .prweb.com/prfiles/2011/12/12/9036299/Allrecipes_2012_MeasuringCup.pdf.

Rodríguez, D. (2007). The political logic of the non-profit industrial complex. In INCITE! Women of Color Against Violence (Ed.), The Revolution will not be funded (pp. 21-40). Cambridge, MA: South End Press.

Rothgerber, H. (2012). Real men don't eat (vegetable) quiche. Psychology of Men \& Masculinity, 14(4), 363-375. DOI: 10.1037/aoo30379.

Rothgerber, H. (2014). Efforts to overcome vegetarian-induced dissonance among meat eaters. Appetite, 79, 32-41. DoI: 10.1016/j.appet.2014.04.003.

Rothgerber, H. (2015). Can you have your meat and eat it too? Appetite, 84, 196-203. DoI: 10.1016/j.appet.2014.10.012.

Rothgerber, H., \& Mican, F. (2014). Childhood pet ownership, attachment to pets, and subsequent meat avoidance. Appetite, 79, 11-17. DOI: 10.1016/j.appet.2014.03.032.

Ruby, M. (2012). Vegetarianism. Appetite, 58, 141-150. DOI: 10.1016/j.appet.2011.o9.019.

Ruby, M., Heine, S., Kamble, S., Cheng, T., \& Waddar, M. (2013). Compassion and contamination. Appetite, 71, 340-348. DoI: 10.1016/j.appet.2013.09.004.

Shapiro, K. (1994). The caring sleuth: Portrait of an animal rights activist. Society \& Animals, 2(2), 145-165.

Staggenborg, S. (1988). The consequences of professionalization and formalization in the pro-choice movement. American Sociological Review, 53(4), 585-605. DoI: 10.1.1.473.2120.

Stahler, C. (2011). How often do Americans eat vegetarian meals? Retrieved July 29, 2017, from http://www.vrg.org/journal/vj2011issue4/vj2011issue4poll.php.

Stallwood, K. (2013). The politics of animal rights advocacy. Relations: Beyond Anthropocentrism, 1(1), 47-57.

Technomic. (2015). Seafood and vegetarian fare provide better-for-you alternatives and minimize the veto vote. Retrieved July 29, 2017, from http://www.prnewswire.com/ news-releases/seafood-and-vegetarian-fare-provide-better-for-you-alternativesand-minimize-the-veto-vote-300066741.html. 
Timko, C., Hormes, J., \& Chubski, J. (2012). Will the real vegetarian please stand up? Appetite, 58(3), 982-990. DoI: 10.1016/j.appet.2012.02.005.

Tufekci, Z. (2014). The medium and the movement. Policy and Internet, 6(2), 202-208. Vegan Outreach. (n.d.). Defining 'vegan'. Retrieved August 6, 2017, from https://www .veganoutreach.org/advocacy/definingvegan.html.

Vegan Outreach. (2004). No thanks, I like meat. Vegan Outreach Newsletter, 13(2), pp.1-2. Vegan Outreach. (2015). Guide to cruelty-free eating. Davis, CA: Vegan Outreach.

Vegan Society. (2014). 'Love vegan' sets the benchmark. The Vegan, Autumn, p. 6.

Vegan Society. (2016). There are three and half times as many vegans as there were in 2006, making it the fastest growing lifestyle movement. Retrieved November 1 , 2016, from https:/www.vegansociety.com/whats-new/news/find-out-how-manyvegans-are-great-britain.

Vegetarian Resource Group. (2016). How many adults in the U.S. are vegetarian and vegan? Retrieved August 7, 2017, from http://www.vrg.org/nutshell/Polls/2016_ adults_veg.htm.

Vegetarian Society. (2015). Number of UK vegetarians. Retrieved November 1, 2016, from https://www.vegsoc.org/sslpage.aspx?pid=753.

Vinnari, M., \& Vinnari, E. (2014). A framework for sustainability transition. Journal of Agricultural and Environmental Ethics, 27(3), 369-396. DOI: 10.1007/ s10806-013-9468-5.

Voucher Codes Pro. (2015). A third of 'vegetarians' eat meat when drunk on a night out. Retrieved November 1, 2016, from http://www.telegraph.co.uk/news/ uknews/11918og1/Athirdofvegetarianseatmeatwhendrunkonanightout.html.

Walsh, E., \& Warland, R. (1983). Social movement involvement in the wake of a nuclear accident. American Sociological Review, 48(6), 764-780.

Wansink, B., Shimizu, M., \& Brumberg, A. (2014). Dispelling myths about a new healthful food can be more motivating than promoting nutritional benefits. Eating Behaviors, 15(2), 318-320. DoI: 10.1016/j.eatbeh.2014.03.016.

Wiig, K., \& Smith, C. (2008). The art of grocery shopping on a food stamp budget. Public Health Nutrition, 12(10), 1726-1734. DOI: 10.1017/S1368980008004102.

Winograd, N. (2007). Redemption. Los Angeles, CA: Almaden Books.

Worsley, A., \& Skrzypiec, G. (1998). Teenage vegetarianism. Appetite, 3o(2), 151-170. Do I: 10.1006/appe.1997.0118.

Wrenn, C. (2016a). Professionalization, factionalism, and social movement success. Unpublished dissertation. Colorado State University: Fort Collins, CO.

Wrenn, C. (2016b). A rational approach to animal rights. London, UK: Palgrave Macmillan.

Zeisler, A. (2016). We were feminists once. New York, NY: PublicAffairs. 